\title{
An attack on the Cross: Spiritual leaders' accounts of fear and resilience during COVID-19 pandemic
}

\author{
Mammusa Rosinah Lekoa \\ Teaching \& Learning Centre \\ University of Zululand \\ Kwa-Dlangezwa, South Africa \\ E-mail: lekoam@unizulu.ac.za \\ Sibusiso Louis Ntuli \\ Department of African Languages and Culture \\ Faculty of Arts, University of Zululand \\ Kwa-Dlangezwa, South Africa \\ E-mail:ntulisı@unizulu.ac.za
}

Doi: https://doi.org/10.46222/pharosjot.102.212

\begin{abstract}
This paper provides accounts on the impact that COVID-19 and the subsequent lockdown(s) had on the Church and its leaders in the South African context. The study explores challenges that the leaders faced and how they dealt with them to remain standing despite their fears. The context is COVID-19 pandemic, which brought mass deaths, fear, confusion and frustration to congregations globally. Church leaders faced a challenge to show resilience amid fear because they too were directly affected. Governments introduced regulations that imposed lockdowns to control the spread of the virus. Limiting contact by restricting distance amongst citizens. The church was one sector that could not operate. Although some sectors were never declared essential services like churches, this left vulnerable communities without support in the face of fear. Spiritual leaders had to demonstrate resilience to support the congregants. The key question the researchers seek to understand is to what extent did the church remain resilient during COVID-19 pandemic? And how did the church leaders deal with fear despite anointing and expectations from the congregants and communities? A qualitative approach was used in this study. COVID-19 has shown that Church leaders are humans and they are also fearful, however their faith in God has assisted them to show resilience even at this difficult time. The study also asserts that governments should consult different groupings of faith-based organisations, not only those that are under organised bodies before embarking on restrictions for pandemic control. Communities encompass many churches and leaders require support to assist them from church members.
\end{abstract}

Keywords: Church, spiritual leaders, resilience, COVID-19, rural communities, Zululand.

\section{Introduction}

The COVID-19 pandemic affects the mental health of communities and their leaders. In December 2019, in the city of Wuhan in China, the Coronavirus (COVID-19) was identified and declared a pandemic, and in March 2020, by the World Health Organisation (WHO) (Durkin et al., 2020). The virus spread fast and people got affected and died in numbers. People and governments globally got anxious and experienced fear. Countries adopted several strategies to control the virus, including imposing lockdown rules. Amongst several measures, the rules required that people keep distance from each other; isolate themselves and avoid social interactions. Worse still, many businesses were ordered to shut down, thus 
denying job opportunities to scores of people. These strategies hurt several communities' social fibre (Durkin et al., 2020). People lost jobs and communities were gripped by constant fear as family and community members succumbed to death. Many were left desperate for food and other lifesaving amenities.

Researchers commissioned research studies to understand the impact of the virus, although most research efforts focused mainly on medical interventions with less regard to social sciences research. Governments are criticised for the insufficient efforts to fight the spread of the virus, including the development of the vaccine. Also, the global countries' failure to learn from previous experiences such as the Haiti earthquakes and Ebola outbreak (s) makes the impact of COVID-19 worse (Entrees et al., 2020). Communities, especially those from the rural areas, lived in fear. Despite less or no support from the government, communities developed resilience to cope with the pandemic. Communities experienced high amounts of stress because the pandemic could not allow them to live and do things normally. People died in large numbers and the deceased could not be given proper and respectful burials which compromised the burial rites of those who passed on (Omonisi, 2020). Cultural and religious practices could not be observed, leaving families in distress (Entress et al., 2020). When things happen, normally the communities usually receive support from their church and community leaders to cope with loss.

\section{Resilience}

Resilience is associated with the positive ability to deal with threatening or stressful situations. It is a means of coping when faced with hostile difficulty. Christensen (2008) views resilience as implementing psychological support that surpasses the mere provision of shelter, food, and medical care. Cowley (2008) views resilience as a process or phenomenon reflecting mind adjustment, despite conditions of risk. Cowley (2008) asserts that resilience is the capacity of successful adaptation despite situations that are rather threatening. Campbell (2016) argues that resilience is a positive change amid severe challenges. The study posits that, for resilience to prevail, an individual first needs to experience trauma. Trauma can be viewed as the personal infection of COVID-19, as well as being affected by the disease. This can be in the form of illness of family members, friends, colleagues and church members, which often culminated into deaths. According to Campbell (2016) resilience takes a lot of time in order to get established. Once it gets established, then a resilient individual does not easily get stressed. However, if he/she does, they are able to remarkably recover from the situation.

In a church, faith plays a significant psychological role in maintaining resilience, and this has been seen in different groupings of religion like Christianity, Hinduism, Buddhism (Koenig, 2020). Places of worship, like other institutions, were closed in order to control the spread of the virus and maintenance of social distance. While it was difficult to adapt to a new norm of connecting home and prayer. Churches relied on the internet to connect and preach the word of God. Several institutions of faith used social media to connect to followers to provide support and prayer (Masoga, 2020, Dein et al., 2020). Believers used the Bible, especially 'The book of Revelation' to interpret the pandemic situation as the end of times and others believed that the second coming of Jesus is closer. Some churches disregarded the health measures proposed by Governments to control the impact and spread of COVID-19. Instead, they continued to congregate and as a result contributed to the spread of the virus.

COVID-19 rules required that people isolate themselves from each other in control of the spread of the virus. This is one of the key and effective measures to control the spread of coronavirus. However, isolation has been previously associated with 'increased health diseases and affect mental health' (Roberto et al., 2020). 


\section{COVID-19 Fear}

The Oxford South African Concise Dictionary (2010:425) defines fear as:

An unpleasant emotion caused by the threat of danger, pain or harm. " (fear for) a feeling of anxiety concerning the outcome of something or the safety of someone " the likelihood of something unwelcome happening.

Indeed, COVID-19 inflicted danger of people being infected by the vicious illness, fear of the unbearable pain that infected people went through and the overarching and impending death that went with the disease. Since COVID-19 also had flu-like symptoms like coughing, suddenly a mere cough and a sneeze became horrendous as people feared for the worse.

Fear for pandemics is not a new thing (Riva et al., 2014) and continues to be relevant today. The Bible demonstrates the fear that was associated with plagues; and Israelites interpreted it to be the sign of sin and punishment by God (check Exodus 9:14, Numbers 11:33, 1 Samuel 4:8, Psalms 89:23, Isaiah 9:13). Fear is a psychological outcome of COVID-19. In South Africa fear was specifically associated with loss of jobs, not enough food and the virus spreading to vulnerable groups of the society (Stiegler and Bouchard, 2020). What is interesting in South Africa is how the pandemic induced fear was linked to apartheid experiences. The study that focuses on HIV women in South Africa found that those who experienced apartheid laws panicked more because the Disaster Management laws reminded them of the atrocities faced during the apartheid era.

\section{Purpose}

The COVID-19 pandemic period has been stressful to communities globally. The South African government is trying to control the spread of the virus with lockdown regulations. Yet, the additional strain of the virus demonstrated to spread fast and contributed a lot to the second wave, which left communities further in fear as they lost more family members and friends. The anxiety and fear associated with the virus persist. Therefore, under this situation, it is important to understand the experiences of those who are leaders in the communities who face the severity of the virus and the pressure of still leading the people.

This article is an extract of the larger COVID-19 study which interviewed traditional leaders, traditional healers and spiritual leaders. The paper focuses only on the verbal accounts of selected spiritual leaders from one District Municipality. The aim of the article is to present the experiences of the spiritual leaders during the pandemic in terms of how they maintained resilience. Also, to present the narration of their stories of fear of the virus despite the expectation of leadership and hope from congregants and communities at large.

\section{Theoretical framework}

The study uses the Theory of Resilience. Vetter (2017) holds that resilience is an ability to recover and endure after a catastrophic event. Resilience seeks to minimise psychological damage when all else seems to fail. The Resilience Theory then embraces ways and means of addressing psychological trauma. The theory reinforces strategies meant to minimise the psychological trauma as visited upon the religious leaders by the COVID-19 pandemic. The Dictionary Unit for South African English (2010), maintains that resilience is 'an ability to recover quickly from hard conditions'. The study then focuses on the ability of religious leaders to recover after a difficult situation, which is the prevalence of the pandemic amongst their flock, including themselves, their families and communities. Almedom and Tumwine (2008) 
view the theory of resilience as a lens focussing on the state of helplessness leading to invincibility.

The study utilised the risk resilience paradigm. Hammond (2011:02) bases his outlook on the resilience paradigm:

If we think we are fragile and broken, we will live a fragile, broken life. If we believe we are strong and wise, we will live with enthusiasm and courage. The way we name ourselves colours the way we live. Who we are is in our own eyes. We must be careful how we name ourselves.

Based on Hammonds view on the resilience paradigm, this study posits that 'what we make out of our lives is all in the state of mind'. The resilience paradigm abhors an all-encompassing vicious cycle of the state of mind of feeling at risk. If left unattended, one may end feeling at risk of being at risk, which eventually becomes one's DNA.

\section{Methodology}

The current article is the result of a subset of the larger COVID-19 study conducted in the rural uMkhanyakude District, Kwa-Zulu Natal Province, South Africa. The original study used a mixed method approach. The current extract is taken from the qualitative part of the original study which interviewed traditional leaders, traditional healers and spiritual leaders to understand their experiences since the beginning of lockdown in South Africa. For this article, the authors' attention was on the spiritual leaders since the study focuses on them. The study intended to explore their mental strength during the pandemic. The participants were asked to reflect on the 1) Their leadership roles in the midst of COVID-19, how the virus affected their daily work (like conducting funerals in the midst of infections) and how they remained standing despite the challenges, 2) Personal understanding of corona virus including local names given to the virus, 4), Social Distancing including indigenous ways that were previously used to social distance, 3) Hygiene and sanitation including washing of hands, availability of water, access to sanitisers and the practicality of frequent washing of hands5) whether they were sufficiently consulted and 6) how communities responded to the lockdown regulations and finally 7) the local practices they believed could manage and prevent COVID-19 in rural communities. Ethical approval for the study was granted by the University of Zululand.

Although there were no specific questions on coping and being resilient amid fear, during the interviews, the participants continued to reflect on their fears, and indirectly or directly, the role of their faith in their resilience and coping strategies. As a result, the findings are based on the verbal confessions of the spiritual leaders on the expression of their fears and resilience strategies they used. To analyse data, the text thematic analysis was used. The data was categorised into two broad themes: fear and resilience accessions and sub-themes were further created under each broad theme.

\section{Sampling}

Within larger groups consisting of leaders from other sectors, six church leaders from uMkhanyakude District, KwaZulu-Natal Province, South Africa, were interviewed. Their age ranged from 40 to 85 . Most had served for a long time as church leaders and had considerable experience in performing church duties. The purposive sampling method was used, as the main aim was to interview a focus group of spiritual leaders in particular. All research ethical issues were discussed with the participants before the interviews were done. These included that the interview was voluntary, non-disclosure of their personal names and those of their establishments, the right to withdraw from the interview anytime when they felt like doing so, that the interview recordings would be kept in a safe place for audio and text analysis and would be disposed of once the study was completed. 


\title{
Data Analysis and Findings
}

This article reports the verbal confessions of spiritual leaders from rural communities in Northern KwaZulu Natal. The extracts are from the voices of spiritual leaders who participated in four focus group interviews done in Hluhluwe (x 2 interviews), Jozini (x 1 interview) and Mtubatuba (x 1 interview) that included traditional leaders and traditional healers. The participants come from the charismatic churches, Zion and Nazareth Baptist Church (commonly known as Shembe). No actual names are used in the reporting of the findings to protect the identity of the participants. Responses from spiritual leaders follow below:

\section{The empowerment and education of spiritual leaders about COVID-19}

This theme refers to the empowerment and education provided by the government or any authority to spiritual leaders. When probed if spiritual leaders were given some education about their role in the fight against COVID-19, pastor M (51 years old) had the following to say:

\begin{abstract}
No, we were never educated about our role in the fight against COVID-19. We were never empowered such that we could become agents of change in the church and communities at large. the little that we are doing, we simply do just because we are spiritual leaders. There is absolutely nothing that we were taught. We were never trained and perhaps given funding to enable us to work with government departments such as the health or even the Municipality, in the fight against COVID-19. We were just thrown into the deep end and left to see to our own survival. It was only when the lockdown was about to be lifted that we were informed of the obligations we had to fulfil as the church.
\end{abstract}

Although the role of spiritual leaders in providing support to the health sector and spiritual guidance to communities is known. Nevertheless, the findings suggest that spiritual leaders were ill prepared to play a positive and informed role in the fight against COVID-19. This is despite the expectation and demand for faith based and spiritual leaders to provide support to others during grief and illness (Corpuz, 2020).

\section{Spiritual leaders faced with an extremely dangerous situation}

As used here the theme facing extremely dangerous situations refers to any situation that leaders face and is linked to the pandemic. These include lack of information to protect themselves, the church and general communities; possible dissatisfaction or blaming from the congregants who felt neglected. The study focuses on how resilience enabled the spiritual leaders to cope with those dangerous situations.

Interviews held with leaders of various faith organisations revealed that during the initial stages of COVID-19 there was scanty understanding of the disease amongst themselves and communities they serve. This indicates that spiritual leaders faced an extremely dangerous situation on all fronts. Spiritual leaders on the one hand faced the wrath and blame from their congregants who felt deserted when leaders suddenly became invisible in compliance with COVID-19 regulations and on the other hand were chided by government authorities for diligently executing their duties, which bordered on defiance of the COVID-19 regulations. Spiritual leaders indicated that they had to deal with extreme fear when faced with an undesirable challenge, amongst other things, that of conducting funerals especially when the deceased were confirmed COVID-19 cases. One leader confessed that:

when a person dies we end up being afraid to even go visit the family 'siyokhala nabo' (console them). Before a person's body arrives from 'emakhazeni' (mortuary) we would try to visit that home during the week, we would sit under 
the tree in an open space, with other spiritual leaders to maintain social distancing". (Leader K, 57 years old male from Hluhluwe, Zion Church leader)

Church leaders were adamant that they took charge and educated their flock about COVID19 when they took to the pulpit. Another pastor suggested it was important for spiritual leaders to do research about recent developments plaguing their communities so that when they spoke, they speak and act from an informed position. Just as the book of Hosea 4:6 maintains that 'My people are destroyed for lack of knowledge'. However, most indicated that fortitude and commitment to the call of duty seemed to pull them through. Leader Gumede says,

\begin{abstract}
We were never taught about the virus except, when I lost my son and wife within two weeks, induna yenkosi called the hospital to come and check on me and sanitised people. It is really hard for me, I don't even have money for 'abeluleki (counsellors/ psychologists), I prayed and trusted things will be ok (Leader G, 71 years old male from Hluhluwe, Nazareth Church Evangelist)
\end{abstract}

Spiritual leaders faced danger at personal and duty levels. The above finding is in line with the study done in Ghana where Osei-Tutu et al., (2021) discovered that personally, spiritual leaders struggled to balance their personal and spiritual needs. They suffered during this time both psychologically and spiritually with limited support from the government. To mitigate the danger that comes with the pandemic, at the level of duty spiritual leaders collaborated with each other to support the congregants. They worked in groups or alternated with each other to provide service and support. Like in the Mpukunyoni area, the leaders would send a group of spiritual leaders to represent all churches to a bereaved family and during the funeral they would send one person to lead the service and represent all of them. Hluhluwe leaders also used the same approach in support of each other and the believers.

\title{
Burial processes and practises
}

In this theme, we refer to those processes and practices that are usually observed when a person has passed on.

Funerals led spiritual leaders to mingle with families and community members who were ignorant or had deliberate disregard of the disease and the lockdown regulations. Ignorance and disregard meant that spiritual leaders and mourners alike would get very little protection from the disease. They argued that there would be very little if any Personal Protective Equipment (PPE) and sanitizers, thus exposing everyone in attendance to a higher risk of infection and death. Some of the spiritual leaders interviewed indicated that the disease had infected them, possibly during the performance of their faith-based duties.

Funerals are generally viewed as points of vulnerability that maximise the infection of COVID19. There was a remarkable contravention of the strict regulations amongst others, prohibiting opening up the deceased's coffin for fear of spreading the virus. The opening of the coffin would be done amid a challenge of spacious funeral venues, leading to most funerals being conducted in cramped spaces where there was very little regard for the social distancing regulations. The curbing of funeral attendees to 50 was also an enormous challenge as some nucleus families in the traditional sense easily exceed that number. But when the spiritual leaders tried to address the breaking off limits, they were met with scorn, disdain, and disrespect. Against the spiritual leader's will and advice, funerals proceeded with the number of mourners far exceeding 50 attendees' threshold. When probed if they do have a positive influence in the way funerals are conducted, Pastor M (51 years old) had the following to say:

In funerals, bereaved families are the ones that are very problematic by refusing to adhere to the COVID-19 regulations. You find them crowded in a room that 
has no ventilation, without sanitizers and with no social distancing. If as a leader you try to call them to order, you soon realize that the bereaved family will regard you as unsympathetic.

A church leader indicated that she likely got infected while conducting one of the many funerals. She had conducted two consecutive burials in one family. She did this much against her better judgment, which suggested the deceased had succumbed to COVID-19. Shortly thereafter, she got a positive diagnosis of the disease. Elsewhere, some argue "COVID-19 is a magnifying glass that exposes the disparities brought by the intersection between religion and race" (Boddie and Park, 2021). Although this work was done in the USA on Black and Latino communities, it has resonance with the current study in that the spiritual groupings that are reported in the current research are in rural areas where most believers are vulnerable groups. The spiritual leaders were mostly left on their own to support and assist the communities who sometime were unappreciative of the efforts of their leaders.

Another dominant church in Kwa-Zulu Natal is the Nazareth Church (Shembe). The Shembe church is one of the churches that still follows strict and traditional practices when it comes to burials. Even though they respected the Covid-19 regulation as stipulated by the government. However, there was an anxiety regarding the death rite of the deceased and the expenses towards the family which had to still do the rituals after the burial happened.

\begin{abstract}
When a person dies, there are rituals we perform until the burial of the deceased, then after. We had to respect the government laws, we stopped the practice... but this has left us anxious, that now families (more especially with children) are left with a lot of expenses that could have been dealt with. Because with every abnormality that goes with the death of a person, there has to be cleansing. With a Covid-19 case, the family has to slaughter a goat for ukumkhipha emakhazeni (cleansing the morgue), another goat yoku geza iplastic (cleansing the plastic) and a goat for the cleansing of the children. This is worrying us a lot ' (Leader G, 71 years old from Hluhluwe, Nazareth Church, Evangelist).
\end{abstract}

\title{
Access to resources and distribution thereof
}

As used here, access to resources and distribution means resources that assist with control of coronavirus and community support like personal protective clothing, sanitizers and food to distribute to the needy. While some community sectors received monetary and physical resources from the government to cater for Personal Protective Equipment (PPE) amongst other things, the faith-based organisations were one of those left out in the lurch. An enquiry around access and distribution of resources clearly received a negative response. Pastor $M$ (51 years old) had the following to say: "We as spiritual leaders are suffering, we really are. Sometimes we and our families go to bed on empty stomachs. The idea of assisting our flock then becomes far beyond our reach".

Spiritual leaders felt that they have always been left to fend for themselves, much worse during the subsequent lockdown(s) when congregants could not converge in places of worship and be able to make offerings, amongst other things. Such is the situation that the spiritual leaders confessed that they sometimes can barely feed their own families. But the congregants did not solely felt the impact of COVID-19. Respondents showed that their rural setting caused the worshipers to develop and run small businesses such as fruit and vegetable vending, as well as tuck shops. When the lockdown came, these small businesses had to close shop, leaving their owners with no income and no means of survival. The lockdown had an adverse effect on the finances of the church. As most churches raise their funding from collections, if members cannot attend church services, the collection of offerings cannot be done. Pastor $\mathrm{M}$ (51 years old) had the following to say: 
The church has been severely disrupted by the lockdown. We can only do collections during church services and if worshipers cannot attend, we lose funding opportunities. When we were eventually allowed to convene, we were expected to provide ourselves with many things like; thermometers, sanitizers and masks after going for several months without doing collections. This has made things very difficult for the church.

Pastor C (59 years old) who is a member of the Local Command Council was at pains in explaining the exclusion of the Church Sector from the Government COVID-19 funding:

We did raise our concern about the lack of government funding to the church. However, the disappointing response was they could not satisfy the churches as that exercise would consume a lot of funds. The idea that we got was that the church was something that we should do on our own. But they do need us when looking for prayer and during elections. I think it is better that we just do not vote

According to some spiritual leaders, there was a remarkable shortage of water supply in their areas, although some maintained that there had been some improvements regarding water supply in their areas.

\section{Preferential treatment in health amenities}

Pastor C (59 years old) showed that when he fell ill, he was taken to a local hospital by ambulance, but sadly had to wait from 9 am until $6 \mathrm{pm}$ before a doctor could attend him to:

I will not lie to you. The situation in hospitals is very challenging. I was taken to the hospital by ambulance and had to wait for hours on end before I could be attended to. When the nurses finally attended to me, they could only give me a thin sheet with which to cover myself, when it was very cold in the ward.

This went on until the nursing staff got a hint that he was in fact a man of the cloth and suddenly things changed for the better. He was then offered a warmer and comfortable blanket and staff suddenly warmed up to him. When probed if this suggested that there was preferential treatment in government hospitals, pastor Cele confirmed this:

To tell you the truth, you can never survive in government amenities if you are not well connected. I got attention because the nursing staff heard that I am a pastor as well as a member of the Local Command Council and things suddenly changed for the better.

He indicated that it was a well-established fact that if one is not 'well connected', one will definitely receive the worst handling by health care givers. Pastor K (56 years old) who was not as fortunate, had to discharge herself from hospital with no medication and had to revert to traditional medicinal herbs for help:

I just could tell that I was not getting any fair treatment from the doctors and the nursing staff. I then asked the doctor to discharge me and I was discharged without any medication. When I got home, I had to rely on steaming, using the gum tree leaves and umhlonyana.

Probed if her use of the traditional herbs was accepted by her congregants, she confidently replied by saying: "I had no choice. It was a matter of life and death, and I fortunately lived to tell the story."

Spiritual leaders alluded to the stigma that COVID-19 has gained, unwittingly so. Caregivers then often seem reluctant to give their-all in treating the victims. 


\title{
Gender based violence within the church
}

Spiritual leaders have been called to perform activities far removed from their call of duty during the era of the lockdown(s). Because of the prevalence of migrant labour in most black families, when the lockdown came, some families only got to spend more time together for unusually protracted periods. As it would be, the lengthened period spent together had its flip side, with more family feuds and gender-based violence coming into play. In such instances, and in particular where congregants were involved, spiritual leaders were then called upon to act as peace brokers. Pastor $\mathrm{M}$ narrated the following two episodes:

\begin{abstract}
I received a call in the middle of the night indicating that my church's family members had got into a heated fight. When I got there, I discovered my congregant couple had got into a hot family feud and had consequently stabbed one another, inflicting severe injuries to one another. In another incident a mother visited his son in a rented place owned by my church's congregants. The son's girlfriend mistook his boyfriend's mother for another girlfriend and after getting into a blind rage of jealousy, had attacked his boyfriend's mother, inflicting severe injuries.
\end{abstract}

In both incidents, the pastor had to intervene in incidents that were rather far removed from his call of duty. Noticeably, though, the pastor put the blame squarely on the lockdown for both troubles. In his own words, "both incidents would not have occurred probably if the people involved had not been brought together by the consequences of the COVID-19". Resilience though, enabled him to deal with both incidents.

\section{The stigmatisation and demonisation of COVID-19. The attack to the cross}

Some communities are experiencing stigmatisation of COVID-19 in the same breath in which HIV/AIDS has been stigmatised. Pastor M (51 years old) had the following to say:

\begin{abstract}
Another problem is the stigmatisation of COVID-19 in the same way that AIDS has been viewed, A person infected by COVID-19 is usually viewed in the same way that an AIDS sufferer is considered. This then makes COVID-19 people to become reluctant to disclose their status for fear of victimisation in one way or the other.
\end{abstract}

Some of the interviewed spiritual leaders are of the opinion that COVID-19 is nothing but a demon that attacks and derails the church. They view COVID-19 as a blatant attack on the church also referred to as the cross. A pastor in Jozini had the following to say:
I view this COVID-19 as an attack on our faith, which has come to place a wedge between married couples. It is an evil spirit. God is against the idea of drawing his people apart. The COVID-19 has come to draw people apart. It is an evil spirit.

There is a notion that the emphasis that COVID-19 strives where there are many people is misleading. Pastor $M$ expressed:

The emphasis that one should avoid crowds is misleading. It leads one to think that one is safer when one is with one person. It does not say anything that you can get infected by one person. A lot of education still needs to be done around the number of people versus protection.

True to the resilience theory, the general outlook and response becomes that of protecting themselves and the faith-based communities against the demon with prayer, fasting, 
abstinence and many other rituals that different faiths normally perform in the purging of demons.

\section{Social distancing versus wedlock intimacy}

One of COVID-19 regulations is to practice social distancing. The idea of social distancing poses a serious threat against one pillar of wedlock, which is intimacy. Pastor Cele (59 years old) confessed that:

For me it is very difficult to practice social distancing within my home and family. We still share everything with my wife and my children, even the idea of the wearing of face masks is difficult to practice at home. We wear face masks only when going out to town and elsewhere.

There may be little adherence to COVID-19 regulations within family spaces. This takes place despite the warning that the young ones often become carriers of the virus and frequently remain asymptomatic. Could the infected elderly be looking for the sources of their infection from afar when the enemy is well within the household?

\section{Apathy amongst the church}

Some worshippers are said to be reluctant to attend services knowing that they will not be blessed 'ukubekwa izandla' because the leaders are still prohibited to touch them. Pastor H (60 years old) had the following to say:

The ritual of 'ukubeka izandla' (the laying on of hands) in line with the social distancing protocols can no longer be performed. Now, worshipers feel that attending church has lost all meaning as the priest/pastor will not be able to touch and thus cleanse them.

Church leaders reported having tried to conduct services online. A major hiccup though was that some members do not have gadgets such as smartphones enabling them to participate in such services. It now appears that going to church is taking on a rather new direction. Some of the worshippers are fast losing touch with the church due to the current arrangements. While some worshipers welcome the new time and travelling saving methods of worshipping, they are, however, not at ease with sermons conducted through smartphones as some cannot afford those rather expensive gadgets. But besides the expenses that come with the smartphone like the costly data, some worshippers feel the method itself is aloof and too distant. The elderly church members in particular often get left behind from virtual and online church services.

\section{Discussion}

The work of spiritual leaders is in its nature stressful and thus may cause "moral injury and psychological trauma" (Osei-Tutu et al., 2021). Spiritual leaders have remained resilient and with fortitude in spite of innumerable challenges that they have had to deal with during the era of COVID-19 and the accompanying lockdown(s). The challenges include but are not limited to; poverty, unemployment, sexual and gender-based violence, the serious threat of the disease itself, the loss of revenue due to lockdown(s), congregants refusing to adhere to lockdown regulations during funerals, death of immediate family and church members, unfair blame for deserting church members, unfair expectations to mediate in church and family disputes during lockdown as well as the lack of support from government and municipality staff. Fear amongst the worshippers who are still reluctant to go to places of worship for fear of getting infected with the disease. Worshippers are said to harbour extreme fear to attend un-sanitized church buildings. Thus, the spiritual leaders have to go to extreme measures to prove the safety of their congregants, often coming at high expense. When spiritual leaders 
could not attend to their followers through home visits and the like, worshipers felt deserted. The leaders suggested churches experienced a steady exodus of worshippers as some felt they needed to get themselves new spiritual homes where they could feel welcomed and cared for. There is a sense among spiritual leaders of not getting what they deserve. That often when everyone needs prayer, then spiritual leaders are remembered, but during the distribution of government funds (as during COVID-19), they are left on their own. Priests and spiritual leaders alike feel they play a huge role in rehabilitating wayward individuals and hard-core criminals, which saves a lot of government finances.

Despite all these challenges, spiritual leaders remained resolute and continued conducting what most people viewed as risky activities such as funerals even when those were of confirmed COVID-19 deaths. They were amongst the first sectors to register their request to the government of the day to consider uplifting the lockdown, and did not hesitate in reopening their churches when the first opportunity presented itself. Some spiritual leaders were indeed infected with the COVID-19, but remained resilient and went back to perform their duties soon after recovery. The study reiterates that prayer has been the main conduit that religious leaders have used in their fight against COVID-19. This finding is consistent with the findings of Osei-Tutu et al., (2021) where spiritual leaders used lockdown for prayer groups where they prayed with others and shared the word of God.

\section{Conclusions}

Crippling with the realities of COVID-19, especially from a context of a rural area with fewer resources, is likely to inflict fear and anxiety amongst spiritual institutions leaders and the congregants. In the same token, the positivity and resilience associated with spirituality encourage healing and support for those who are infected and affected. Governments should recognise faith-based organisations while fighting pandemics like Covid-19 because of their role in supporting those who are affected and infected (Roberto et al., 2020). More so, as some spiritual leaders did vent their frustrations at 'being left behind' in the government initiatives of fighting against COVID-19. Spiritual institutions have assets and resources that could be helpful in the fight of pandemics like Covid-19 (Bruce, 2020), hence governments should engage churches, temples and synagogues despite their affiliation to certain religious organisations for example the South African Organisation of Churches in South Africa.

Fear and anxiety is a normal response to a crisis. In the current article, we observe that anxiety contributes to spiritual leaders' struggles to balance their personal lives and the lives of congregants during the lockdowns. The findings suggest a need for psychological interventions or support for spiritual leaders. However, it was not within this article to determine whether the spiritual leaders received psychological support or health intervention; rather, the findings direct us to areas for future investigations

Funding: the study was made possible through support of a grant from South Africa and Sweden University Forum (SASUF). But the opinions expressed in this article are those of the authors and do not reflect the views of SASUF.

\section{References}

Almedom, A.M. \& Tumwine, J.K. (2008). Resilience, Research and Policy/Practice Discourse in Health, Social, Behavioural and Environmental Sciences Over the Last 10 Years. African Health Sciences, 8(S), 1-4.

Boddie, S. C. \& Park, J. Z. (2021). Racializing the Religious during the COVID-19 Pandemic. Religions, 12, 341.

Bruce, M. A. (2020). COVID-19 and African American Religious Institutions. Ethn Dis, 30, 425428. 
Campbell, P.R. (2016). Discovering Principles of Resilience in the Ministry. An unpublished doctoral thesis. Asbury Theological Seminary. Asbury: Kentucky.

Christensen, L. (2008). From trauma to resilience, African Health Sciences, 8(s), 39-40.

Corpuz, J.C.G. (2020).COVID-19: spiritual interventions for the living and the dead. Journal of Public Health (Oxford). 2020 Sep 15:fdaa167. doi: 10.1093/pubmed/fdaa167. Epub ahead of print. PMID: 32930714; PMCID: PMC7543557.

Cowley,S. (2008). Developing and Measuring Resilience for Population Health. African Health Sciences, 8(s), 41-43.

Dein, S., Loewenthal, K., Lewis, C. A. \& Pargament, K. I. (2020). COVID-19, mental health and religion: an agenda for future research. Mental Health, Religion \& Culture, 23, 1-9.

Durkin, J., Jackson, D. \& Usher, K. (2020). Touch in times of COVID-19: Touch Hunger hurts, Journal of Clinical Nursing, 30(1-2).

Entress, R., Tyler, J. \& Sadiq, A. A. (2020). Managing Mass Fatalities during COVID-19: Lessons for Promoting Community Resilience During Global Pandemics. Public Administration Review, 80(5), 856-861. by The American Society for Public Administration. DOI: 10.1111/puar.13232

Hammond, W. (2011). A Strengths-Based Perspective. Available online at www. resiliencyinitiatives.ca

Koenig, H. (2020). Maintaining Health and Well-Being by Putting Faith into Action During the COVID-19 Pandemic. Journal of Religion and Health, Oct 2020 59(5), 2205-2214. doi: 10.1007/s10943-020-01035-21 - 10.

Masoga, M. A. (2020). Effectiveness of WhatsApp homiletics in the era of COVID-19 in South Africa. Pharos Journal of Theology, Volume 101. Available online at https://www.pharosjot.com/uploads/7/1/6/3/7163688/article_51_vol_101_2020_unizul.pdf

Omonisio, A. (2020). How covid-19 pandemic is changing Africa's elaborate burial rites, mourning and grieving. The Pan African Medical Journal, 35, 1-4.

Osei-Tutu, A., Kenin, A., Affram, A. A., Kusi, A. A., Adams, G. \& Dzokoto, V. A. (2021). Ban of Religious Gatherings during the COVID-19 Pandemic: Impact on Christian Church Leaders' Well-Being in Ghana. Pastoral Psychology, 1-13. Available online at https://doi.org/10.1007/s11089-021-00954-5

Roberto, A., Sellon, A., Cherry, S., Hunter-Jones, J. \& Winslow, H. (2020). Impact of spirituality on resilience and coping during the COVID-19 crisis: A mixed-method approach investigating the impact on women. Health Care for Women International, 41, 1313 - 1334.

The Dictionary Unit for South African English, (2010). Oxford South African Concise Dictionary. Cape Town: Oxford University Press.

The Holy Bible, King James Version, (2020). Colorado Springs: Brown Books Publishing.

Vetter, K, (2017). The Institute of Resilient Communities. University of California: Berkeley. 